\title{
Commercial fish assemblages on New Caledonian fringing reefs submitted to different levels of ground erosion
}

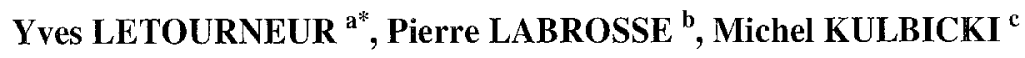 \\ ${ }^{a}$ Université de la Méditerranée, Centre d'océanologie de Marseille, station marine d'Endoume, rue de la Batterie-des- \\ lions, 13007 Marseille, France \\ ${ }^{\mathrm{b}}$ South Pacific Commission, Reef fisheries Secretariat, BP D5, 98848 Nouméa cedex, New Caledonia \\ ${ }^{\mathrm{c}}$ Centre IRD, BP A5, 98848 Nouméa cedex, New Caledonia
}

Revised 12 March 1999; accepted 27 April 1999

\begin{abstract}
A comparative study was conducted in two zones of the Northern Province of New Caledonia, one located windward (east coast) and the other located leeward (west coast). In each zone, three major sectors were investigated: fringing reefs close to areas of important mining activities, fringing reefs close to areas of moderate mining activities, and fringing reefs close to areas free of mining activities. In addition, on the west coast, fringing reefs close to areas of high natural ground erosion were also studied. Only commercial fish species sensus lato were censused on a total of 163 stations, concerning 165 fish species. Substrate characteristics were not different between zones and sectors. However, significant differences were observed for living organisms: live coral cover was higher in non-mining sectors than in mining ones, and algal cover increased with increasing mining activities. The three main descriptors of the commercial fish communities (e.g. mean species richness, density and biomass) have all shown lower values in sectors submitted to the lowest ground erosion levels, although these trends were not all statistically significant. Similar results were found for some of the major fish families, such as the Acanthuridae and Siganidae, whereas other families had no specific pattern, such as the Lutjanidae, or a 'partial' pattern (i.e. on only one coast), such as the Serranidae, Lethrinidae, Mullidae, Labridae and Scaridae. (C) 1999 Ifremer / CNRS / IRD / Éditions scientifiques et médicales Elsevier SAS
\end{abstract}

\section{ichthyofauna / fringing reefs / mining activities / terrigeneous runoff / Pacific Ocean}

Résumé - Assemblages de poissons commerciaux de récifs frangeants soumis à différents degrés d'érosion terrigène en Nouvelle-Calédonie. Une étude comparative a été réalisée pour évaluer les effets des apports terrigènes sur les peuplements de poissons d'intérêt commercial de la province Nord de la Nouvelle-Calédonie. Deux zones sont étudiées, l'une localisée au vent (côte est) et l'autre sous le vent (côte ouest). Dans chaque zone, trois régions principales sont distinguées : récifs frangeants proches de secteurs soumis à d'importantes activités minières, récifs frangeants proches de secteurs soumis à des activités minières modérées, et récifs frangeants proches de secteurs non miniers. De plus, sur la côte ouest, des récifs frangeants proches de secteurs soumis à une forte érosion terrigène naturelle sont également étudiés. Seules les espèces de poissons d'intérêt commercial au sens large ont été recensées (165 espèces) sur un total de 163 stations. Les caractéristiques du substrat ne différent pas d'une zone à l'autre, ni d'une région à l'autre. Én revanche, des différences significatives sont observées pour les organismes recouvrants : la couverture en corail vivant est plus forte sur les récifs proches de secteurs non miniers, alors que la tendance est inverse pour le recouvrement algal. Les trois descripteurs principaux des communautés de poissons commerciaux (richesse spécifique, densité et biomasse) sont plus faibles dans les secteurs non miniers, bien que cette tendance ne soil pas toujours statistiquement significative. Des résultats similaircs sont

\footnotetext{
" Correspondence and reprints: letourneur@ com.univ-mrs.fr
} 
obtenus pour certaines des principales familles de poissons, comme les Acanthuridae et les Siganidae, tandis que d'autres familles ne montrent aucune tendance particulière, comme les Lutjanidae, ou une tendance «partielle » (c'est-à-dire stir une seule des deux côtes), comme les Serranidae, les Lethrinidae, les Mullidae, les Labridae et les Scaridae. (C) 1999 Ifremer / CNRS / IRD / Éditions scientifiques et médicales Elsevier SAS

\section{ichtyofaune / récif corallien / activité minière / apport terrigène / océan Pacifique}

\section{INTRODUCTION}

Fish are clearly one of the most important marine resources on coral reef ecosystems, particularly for developing countries and Pacific island nations. These ecosyssems are 'regularly' submitted to natural perturbations, such as hurricanes [17] or Crown-of-thorn starfish infestations [48, 53]. In addition, and for several decades, the coral reefs have been submitted to an increasing range of human-induced perturbations $[15,20,46]$. In particular, the increase in fish consumption determined a strong increase in the fishing pressure on the reefs of various geographical areas $[18,45]$. In some cases, overfishing is reached and was deemed one of the most serious threats to coral reefs [39]. The other major human-induced disturbances on coral reefs are likely linked to eutrophication processes [34], dredging mining and siltation [3, 11, $14]$, and/or alteration of natural habitats due to urbanisation of coastal areas $[5,28]$.

In New Calcdonia and with the exception of the surroundings of the city of Nouméa (the only really urbanized zone), most of the major potential threats cited above may be considered as unimportant mainly due to a very low human density. However, New Caledonia is characterized by important extensive mining activities focusing on nickel ore, which is largely present on land (third world nickel reserves). Although nickel mining activities have existed since the beginning of the century, the impact of mining on coastal communities has never been seriously assessed. Some information on heavy metals contamination of marine invertebrates, such as echinoderms and molluscs is available, but bioconcentration, toxicity, physiological and/or ecological impact on superior trophic levels, such as fish, were not investigated [12]. However, the removal of all vegetation in order to access nickel ore resources obviously increases the risks of terrestrial erosion and hypersedimentation in coastal areas during rainfall episodes [31]. Thus, nickel mining activities may be considered as a local potentially important threat to coral reefs and their living resources.
As part of a larger study on stock assesment of fish of commercial interest in New Caledonia $[24,25,30]$, we will try here to answer the following questions: do commercial fish communities from fringing reef areas submitted to different ground erosion levels show significant segregation in their main descriptors, i.e. diversity, density and biomass? If so, are these differences linked to a ground erosion and/or levels of mining activity?

\section{MATERIAL AND METHODS}

\subsection{Study area and sampling sectors}

This study was conducted on both the east and west coasts of the Northern Province of New Caledonia, in the southwcstern Pacific Ocean (figure 1). New Caledonia is one of the largest islands in the tropical Pacific $\left(16900 \mathrm{~km}^{2}\right)$ and is surrounded by very extensive barrier reefs delimiting a lagoon of approximatively $23400 \mathrm{~km}^{2}$. In the Northern Province, the current human density is very low: approximatively 41500 inhabitants for the whole Province resulting in a mean density of about 4.2 persons per $\mathrm{km} \mathrm{[1]}$, and only small artisanal fisheries exist there. Average rainfall usually varies between $1.0 \mathrm{~m} \mathrm{yr}^{-1}$ on the west coast and $2.3 \mathrm{~m} \mathrm{yr}^{-1}$ on the east coast [37].

Only the fringing coastal reefs were studied here. On both coasts, three types of fringing reefs have been investigated: fringing reefs close to areas of important mining activities, fringing reefs close to areas of moderate mining activities, and fringing reefs close to areas free of mining activities (figure 1). In addition, on the west coast, fringing reefs close to areas submitted to high natural ground erosion were also studied. In fact, this erosion is not really natural, because it is linked to low and fluctuating vegetation cover due to frequent human-induced bush fires. Thus, a total of seven different sectors was studied. Each sector includes a variable number of stations (i.e. replicates), ranging from 10 to 47 . As recommended [27], the sampling effort in each geographical sector was 


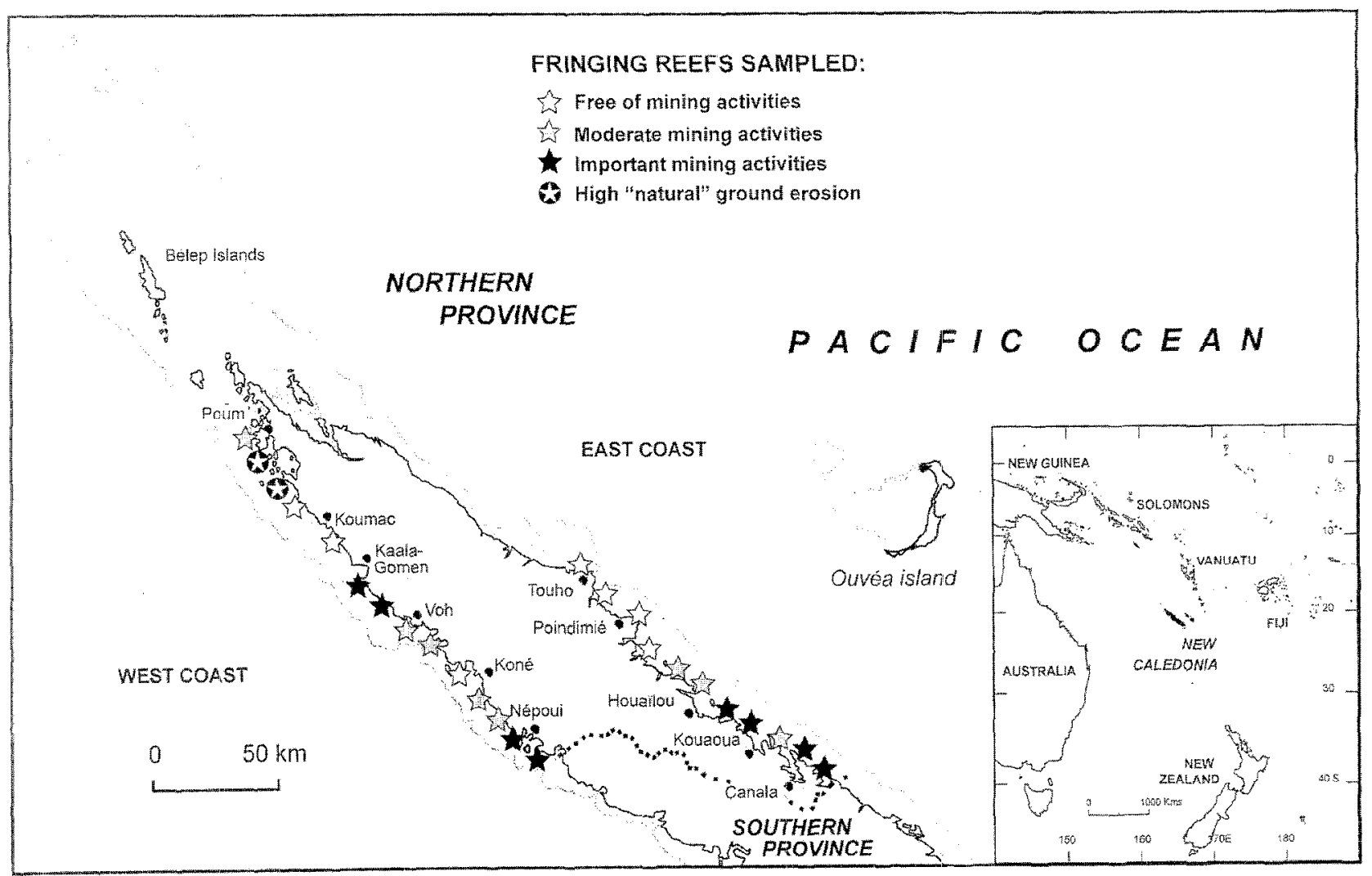

Figure 1. Location of the fringing reefs studied in the lagoon of the Northern Province of New Caledonia, southwestern Pacific Ocean.

proportional to the estimated surface of reef slopes at the sampled depths (2-7 $\mathrm{m}$ on average). A total of 163 stations was investigated.

\subsection{Definition of sectors of different mining activity levels}

Important mining activities occur in New Caledonia, concerning mainly nickel, but also iron, cobalt and chromium to a lesser extent. The main characteristic of mining activities in New Caledonia is that they are all open-cast mines (most of them arc cxtensively or semiintensively exploited). So, it may be concluded that eroded surfaces on peridotite geological substrates are all due to nickel mining activities (SMAI, pers. comm. Service des Méthodes Administratives et Informatiques). Terrestrial images of the SPOT satellite were used to estimate the eroded surfaces close to the different sectors studied. It was not possible to calculate the exact eroded surfaces, due to strong variations in relief topography and declivity between and within sectors. For our purpose, it was however sufficient to have semi-quantitative data of terrestrial eroded surfaces.

\subsection{Fish sampling technique}

Commercial fish communities were studied by visual censuses using the line-transect method [7] at depths which required Scuba diving equipment. This census method is derived from terrestrial procedures, and its precision and accuracy for underwater-based work have been demonstrated $[7,8,22]$. Sevcral authors have also used this method for estimating density of fish populations $[21,31,50,51]$. At each station, two divers censused fish along a $50 \mathrm{~m}$ transect, one on each side of the transect. The observers counted all commercial fish, and recorded the estimated perpendicular distance between the fish and the transect line. Distances were noted in $1 \mathrm{~m}$ intervals for fish between 0 and $4 \mathrm{~m}$ from the transect line, in $2 \mathrm{~m}$ intervals for fish between 5 and $10 \mathrm{~m}$, and in 
$5 \mathrm{~m}$ intervals for fish between 10 and $20 \mathrm{~m}$ away from the transect line. Censuses did not take place if visibility was less than $4 \mathrm{~m}$ from each side of the transect. Density and biomass estimates (see below) are based on the detectability functions of species. This factor is much better accounted for by the method used than fixed width transects or fixed radius points counts for commercial fish species [22]. The size of fish (total length) was estimated using $1 \mathrm{~cm}$ classes for fish ranging from 1 to $10 \mathrm{~cm}, 2 \mathrm{~cm}$ classes for fishes ranging from 10 to $30 \mathrm{~cm}$, $5 \mathrm{~cm}$ classes for fish from 30 to $60 \mathrm{~cm}$, and $10 \mathrm{~cm}$ classes for fish larger than $60 \mathrm{~cm}$. The choice of increasing size classes with fish length follows widely known recommendations [4]. Previous studies [21, 23] indicated that for most species, the difference between observed and actual size was less than $15 \%$.

If fish were in a school or a group, the number of fish was estimated and the perpendicular distance of the closest fish and the furthest fish were recorded. Each sighting occurrence will be called a record. Each record contained the species name, the number of fish sighted, the estimated size of fish, and the distance at which the fish were observed from the transect line. Despite usual bias of visual censuses, mainly for cryptic or shy species, this method is particularly efficient in biotopes where human visits (diving, spearfishing, etc.) are rare, because the fish behavior remains natural [22]. Particular care was also taken for species attracted to the divers and to avoid double counts of fish crossing the transect line. Visual censuses were done at different periods according to zones: austral summer 1995-1996 (approximately from October to March) in the west coast, and austral summer 1996-1997 (approximatively from December to February) in the east coast. In addition and for each station sampled, the substrate characteristics (table I) and cover by living organisms (macroalgae, soft corals, hard corals) were quantified along the transect.

Table I. Characteristics of the different substrate categories.

\begin{tabular}{ll}
\hline Category & Size of particles or characteristics \\
\hline Mud & $<0.0063 \mathrm{~mm}$ \\
Fine sand & $0.0063-0.25 \mathrm{~mm}$ \\
Coarse sand & $0.25-2 \mathrm{~mm}$ \\
Gravel & $2 \mathrm{~mm}-1 \mathrm{~cm}$ \\
Rubble & $1-5 \mathrm{~cm}$ \\
Small block & $5-30 \mathrm{~cm}$ \\
Large block & $30-100 \mathrm{~cm}$ \\
Rock & Massive rocks, to biogenic origin or not \\
Coral head & Coral blocks larger than 1 m of diameter \\
\hline
\end{tabular}

\subsection{Data analyses}

The data of the two observers cannot be used as replicates because the environment within a station may be heterogeneous (for example, when the census was done near the basal part of the reef slope, one diver may have counted on the 'reef side' of the transect and the other on the 'sand side'). Data were thus pooled for each transect. Many density estimators may be chosen [8]. Among them, as mentioned in previous work [51], the most robust for this type of data is

$D_{i}=(2 L)^{-1} \sum\left(n_{i} / d_{i}\right)$ where $D_{i}$ : density of species $i$ (fish $\mathrm{m}^{-2}$ ),

$\mathrm{L}$ : transect length $(50 \mathrm{~m})$,

$n_{i}$ : abundance of species $i$,

$d_{i}$ : average distance of species $i$ to the transect $(m)$.

Average distance for species i was calculated as follow:

$\mathrm{d}_{\mathrm{i}}=\left(\mathrm{n}_{\mathrm{i}}\right)^{1} \sum\left(\mathrm{n}_{\mathrm{j}} \mathrm{d}_{\mathrm{j}}\right)$

where $n_{j}$ : number of fish of species $i$ observed at occurrence $j$, and $d_{j}$ : distance of fish of species $i$ to the transect at occurrence $\mathbf{j}$.

The weight of fishes was calculated from length-weight relationships previously defined [32]. Biomass can be calculated in a similar way to density

$B_{i}=(2 L)^{-1} \sum\left(w_{i} / d_{i}\right)$

where $B_{i}$ : biomass $\left(\mathrm{g} \mathrm{m}^{-2}\right)$, and $w_{i}$ : weight of species $i(g)$.

These different estimates can be calculated for each species or for all species combined. The most robust estimates for global data were obtained using the sum of estimates per species rather than estimates which consider all species combined $[24,31]$. A principal component analysis (PCA) was applied to the three 'global' fish descriptors (species richness, density and hiomass, which were standardized due to their different natures) of the 163 stations. The heterogeneity of dispersion was tested with random permutations of stations between groups (i.e. the seven sectors) [42]. Two-way ANOVAs (coast $x$ type of reef) were performed on each type of data set (species richness, density and biomass). When ANOVAs detected significant differences, a posteriori SNK tests were used for comparison of means. The regression between descriptors of fish communities and substrate characteristics (substrate variables themselves and cover by living organisms) was fitted to the most significant correlation model. The significance of the correlation index (R) was tested according to the degrees of freedom given by the model [27]. 
Table II. Total species richness, mean species richness, mean density $\left(\times 10^{-4}\right.$ indiv $\left.\cdot \mathrm{m}^{-2}\right)$ and mean biomass $\left(\mathrm{g} \cdot \mathrm{m}^{-2}\right)$ per census on the seven sectors studied. Confidence intervals at $\alpha=5 \%$ level are in parentheses. Results of two-way ANOVAs and a posteriori SNK-tests $(\alpha=5 \%)$. Level of significance of ANOVAs: ** $-\mathrm{p}<0.01, *=\mathrm{P}<0.05$, ns $=\mathrm{P}>0.05,-=$ not tested.

Sectors underlined are not stastitically different at a $5 \%$ level (SNK test).

\begin{tabular}{|c|c|c|c|c|c|c|c|c|c|c|}
\hline & \multicolumn{4}{|c|}{ WEST COAST } & \multicolumn{3}{|c|}{ EAST COAST } & \multirow{2}{*}{\multicolumn{3}{|c|}{$\frac{\text { ANOVA }}{\text { Source of variation }}$}} \\
\hline & \multirow{2}{*}{$\begin{array}{c}\text { High } \\
\text { erosion } \\
\text { (WHE) }\end{array}$} & \multirow{2}{*}{$\begin{array}{c}\text { High } \\
\text { mining } \\
\text { (WHM) }\end{array}$} & \multirow{2}{*}{$\begin{array}{c}\text { Low } \\
\text { mining } \\
\text { (WLM) }\end{array}$} & \multirow{2}{*}{$\begin{array}{c}\text { Non } \\
\text { mining } \\
(\text { WNM })\end{array}$} & \multirow{2}{*}{$\begin{array}{l}\text { Non } \\
\text { mining } \\
\text { (ENM) }\end{array}$} & \multirow{2}{*}{$\begin{array}{l}\text { Low } \\
\text { mining } \\
\text { (ELM) }\end{array}$} & \multirow{2}{*}{$\begin{array}{l}\text { High } \\
\text { mining } \\
\text { (ElHM) }\end{array}$} & & & \\
\hline & & & & & & & & Coast $(\mathrm{C})$ & $\begin{array}{l}\text { Type of } \\
\text { reef }(T)\end{array}$ & $(\mathbf{C} \times \mathbf{T})$ \\
\hline No. of stations & 13 & 19 & 10 & 11 & 47 & 22 & 41 & - & - & - \\
\hline Total nb of species & 82 & 94 & 67 & 67 & 132 & 112 & 133 & - & - & - \\
\hline Mean $n b$ of species & $20.9(3.5)$ & $15.9(2.7)$ & $13.9(3.5)$ & $14.1(4.5)$ & $17.0(2.7)$ & $23.5(3.8)$ & $23.8(2.5)$ & $*$ & $* *$ & $\mathrm{~ns}$ \\
\hline Mean density & $470(51)$ & $510(39)$ & $492(50)$ & $358(36)$ & $283(14)$ & $431(56)$ & $425(44)$ & $*$ & $*$ & ns \\
\hline Mean biomass & $194(32)$ & $109(10)$ & $137(14)$ & $98(12)$ & $78(7)$ & $131(17)$ & $171(18)$ & ns & $* * *$ & ns \\
\hline
\end{tabular}

A posteriori SNK-tests :

\begin{tabular}{|c|c|c|c|c|c|c|c|}
\hline Mean nb of species & EHM & ELM & WHE & ENM & WHM & WNM & WLM \\
\hline & & & & & 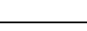 & & \\
\hline Mean density & WHM & WLM & WHE & ELM & EHM & WNM & ENM \\
\hline Mean biomass & WHE & EHM & WLM & ELM & WHM & WNM & ENM \\
\hline
\end{tabular}

\section{RESULTS}

\subsection{Composition, density and biomass of fish communities}

A total of 165 fish species was recorded during this study. The total number of species was lower on the west coast (ranging from 67 to 94 species) than on the east coast (ranging from 112 to 133 species) (table II), but this is most likely due to a difference in the number of stations sampled. More explicit was the mean number of species per census, which follow an increasing gradient with ground erosion level along both coasts (table II). The ANOVAs showed the significance of the factors 'coast' and 'type of reef' on the patterns found (table II). Although differences of mean diversity between 'intermediate levels' of ground erosion were not statistically significant, the differences between the lowest and the highest values were significant on the two coasts (SNK test, $\mathrm{P}<0.01$ ). The mean densitics followed similar patterns, but without clear links to a particular level of ground erosion. However, along both coasts, significantly lower values were found on fringing reefs close to areas free of mining activities (table $I I$ ). Mean biomass increased significantly with ground erosion level on the east coast (table II). No such gradient appeared on the west coast, but the lowest value was found on fringing reefs not submitted to ground erosion and the highest on fringing reefs submitted to high ground erosion. Thus, fish assemblages significantly differed between sectors because each sector was characterized by different triplets of data, i.e. mean species richness, density and biomass. This was confirmed by the PCA which also revealed striking differences in fish assemblages (figure 2). Axis 1 separated centres of gravity of stations of fringing reefs close to areas submitted to high ground erosion levels, from those of fringing reefs close to areas submitted to low ground erosion levels, except in the east zone; axis 2 scparated the two coasts. The test of random permutations is highly significant $(P=0.002)$, underlining that fish assemblages were significantly different between the seven sectors studied. 


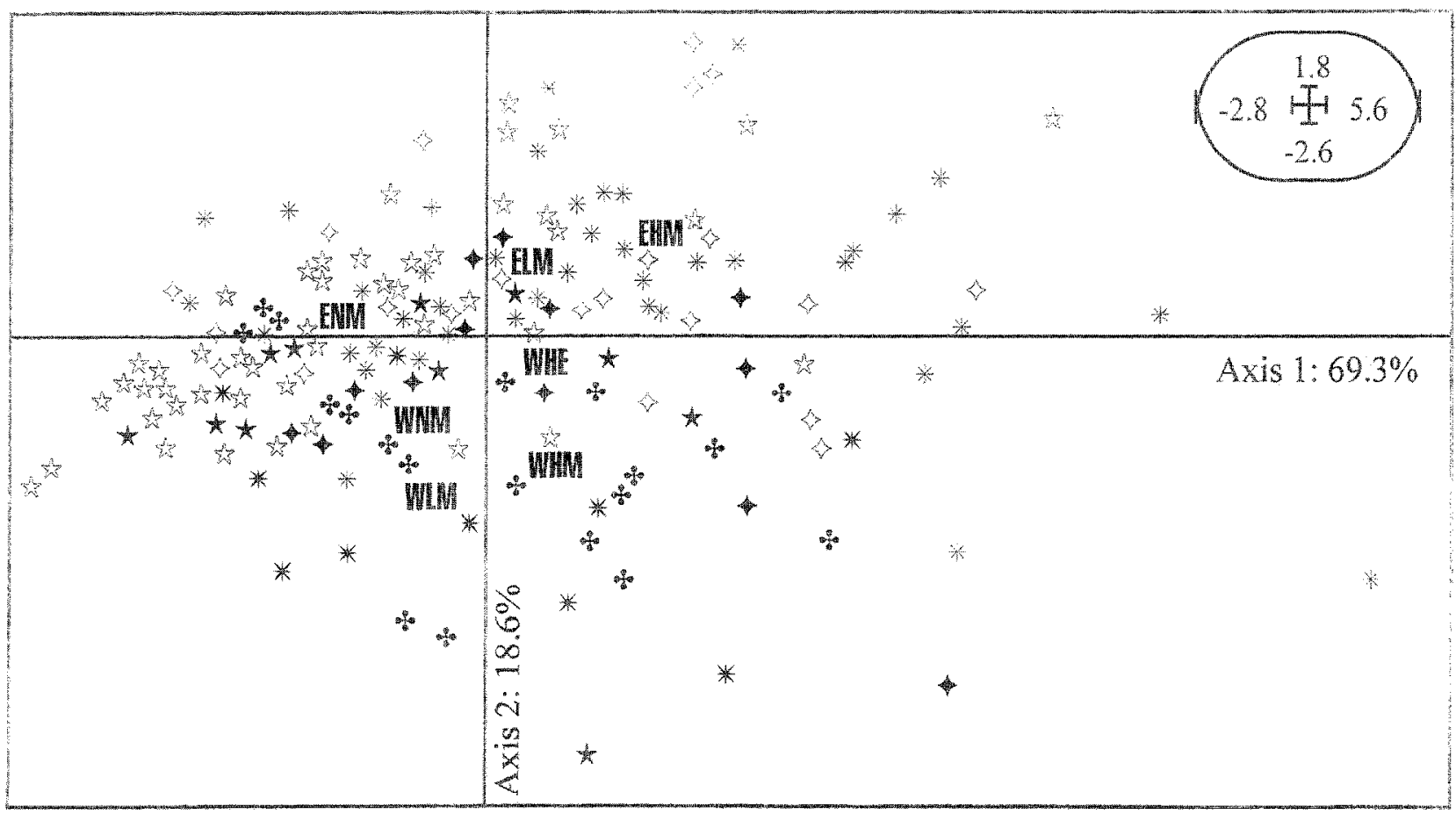

Figure 2. First factorial plane of the PCA monitored on the standardized data of species richness, density and biomass of the commercial reet fish. The position of the centre of gravity of each group of stations is shown as follows: WHE = west coast, high erosion (stations: WHM $=$ west coast, high mining (stations: ${ }^{\circ}$ ), WLM $=$ west coast, low mining (stations: * ), WNM = west coast, non-mining

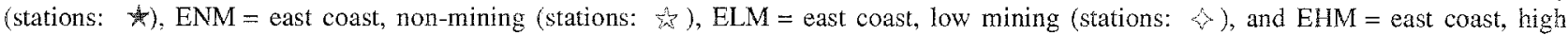
mining (stations: * ).

The main fish families displayed different patterns in response to increasing ground erosion levels. In the first case some families, such as Acanthuridae and Siganidae, had trends similar to those ohserved for the whole ichthyofauna, e.g. an increase of species richness, density and/ or biomass with increasing ground erosion levels (table III). Although these trends are not all statistically significant, significant differences ( $\mathrm{SNK}$ test, $\mathrm{P}<0.05$ ) were found between the lowest and the highest values, such as for the biomass of Siganidae on the east coast. The second case is represented by the Lutjanidae which were relatively indifferent to ground erosion, except for a slight decrease in biomass on the east coast (table III). In the third case, the observed trends appeared only on one coast: the Serranidae, Labridae and Scaridae displayed an increase in species richness, density and/or biomass with increasing ground erosion levels on the east coast (however, the opposite trend is observed for the biomass of Serranidae), and the Mullidae and Lethrinidac on the west coast (table III). These trends are not all significant, but significant differences (SNK test, $\mathrm{P}<0.05$ ) occurred between highest and lowest values in most cases.
Among the major fish species, 24 increased in density and/or biomass with increasing mining and/or ground erosion levels. In most cases, the trends found for these species are, not surprisingly, similar to those of the family to which they belong. This is the case of the serranid Plectropomus leopardus (increase in density and/or biomass with increasing ground erosion levels on the east coast), of the lethrinids Lethrinus harak and Monotaxis grandoculis, the labrid Cheilinus trilobatus, and the scarids Scarus altipinnis, S. ghobban and S. microrhinos (increase in density and/or biomass with increasing ground erosion on the west coast), of the acanthurids Acanthurus xanthopterus and Naso unicornis, and of the siganids Siganus argenteus, S. lineatus and S. puellus (increase in density and/or biomass with increasing ground erosion on both coasts).

Conversely, five other major species displayed a trend oppositc to those of the family to which they belong. This is the case of the labrids Bodianus perditio and Choerodon graphicus, which decreased in biomass with increasing ground erosion (but only on the west coast for the 
Table III. Mean species richness (A), mean density $\left(\times 10^{-4}\right.$ ind $\left.\cdot \mathrm{m}^{-2}\right)(B)$ and mean biomass $\left(\mathrm{g} \cdot \mathrm{m}^{-2}\right)(\mathrm{C})$ per census for the major fish families on the seven sectors studied. Confidence intervals at $\alpha=5 \%$ level are in parentheses.

\begin{tabular}{|c|c|c|c|c|c|c|c|}
\hline \multirow[b]{2}{*}{ (A) } & \multicolumn{4}{|c|}{ WEST COAST } & \multicolumn{3}{|c|}{ EAST COAST } \\
\hline & Figh erosion & High mining & Low mining & Non mining & Non mining & Low mining & High mining \\
\hline Serranidae & $2.00(0.60)$ & $0.95(0.31)$ & $1.70(0.99)$ & $1.36(0.66)$ & $1.25(0.31)$ & $2.55(0.69)$ & $2.12(0.35)$ \\
\hline Lutjanidae & $0.69(0.50)$ & $1.42(0.59)$ & $2.10(1.04)$ & $1.27(0.78)$ & $1.64(0.40)$ & $1.23(0.40)$ & $2.15(0.55)$ \\
\hline Lethrinidae & $0.92(0.41)$ & $0.95(0.34)$ & $0.70(0.20)$ & $0.55(0.31)$ & $0.96(0.20)$ & $0.86(0.35)$ & $1.14(0.30)$ \\
\hline Mullidae & $2.08(0.46)$ & $2.11(0.49)$ & $1.60(0.63)$ & $1.18(0.53)$ & $2.00(0.44)$ & $1.14(0.45)$ & $1.51(0.26)$ \\
\hline Labridae & $2.46(0.62)$ & $1.26(0.58)$ & $1.00(0.55)$ & $1.55(0.57)$ & $1.70(0.40)$ & $3.41(1.03)$ & $2.88(0.48)$ \\
\hline Scaridae & $5.00(1.19)$ & $3.68(0.75)$ & $2.00(1.26)$ & $2.55(0.58)$ & $3.09(0.68)$ & $4.86(1.06)$ & $4.90(0.71)$ \\
\hline Acanthuridae & $4.54(1.04)$ & $2.47(0.57)$ & $2.90(1.18)$ & $3.00(1.27)$ & $3.55(0.52)$ & $3.77(0.85)$ & $3.80(0.60)$ \\
\hline Siganidae & $1.31(0.46)$ & $1.16(0.42)$ & $0.70(0.32)$ & $1.36(0.44)$ & $1.38(0.35)$ & $2.86(0.54)$ & $2.44(0.38)$ \\
\hline \multicolumn{8}{|l|}{ (B) } \\
\hline Serranidae & $264(69)$ & $81(32)$ & $232(81)$ & $155(73)$ & $137(43)$ & $273(66)$ & $260(60)$ \\
\hline Lutjanidae & $1261(1129)$ & $803(676)$ & $2651(1347)$ & $1252(1054)$ & $691(449)$ & $496(458)$ & $544(347)$ \\
\hline Lethrinidae & $193(112)$ & $342(224)$ & $191(165)$ & $61(48)$ & $131(46)$ & $90(37)$ & $111(34)$ \\
\hline Mullidae & $554(284)$ & $456(139)$ & $240(104)$ & $138(80)$ & $270(90)$ & $569(437)$ & $213(93)$ \\
\hline Labridae & $234(81)$ & $118(63)$ & $135(81)$ & $250(108)$ & $113(24)$ & $281(102)$ & $250(51)$ \\
\hline Scaridae & $1095(386)$ & $2155(827)$ & $592(311)$ & $678(366)$ & $74.6(202)$ & $1526(574)$ & $1417(336)$ \\
\hline Acanthuridae & $979(313)$ & $748(207)$ & $726(190)$ & $570(209)$ & $774(109)$ & $669(206)$ & $819(217)$ \\
\hline Siganidae & $309(135)$ & $330(123)$ & $169(80)$ & $318(129)$ & $270(115)$ & $335(73)$ & $360(83)$ \\
\hline \multicolumn{8}{|l|}{ (C) } \\
\hline Serranidae & $20.9(10.5)$ & $4.4(2.8)$ & $12.9(8.9)$ & $8.6(8.9)$ & $15.2(10.1)$ & $12.7(8.7)$ & $9.8(3.2)$ \\
\hline Lutjanidae & $30.4(19.4)$ & $27.6(10.5)$ & $68.9(43.4)$ & $28.2(20.5)$ & $14.1(9.1)$ & $11.7(7.5)$ & $10.9(5.8)$ \\
\hline Lethrinidae & $6.9(4.6)$ & $4.9(2.6)$ & $2.2(1.0)$ & $1.6(0.9)$ & $2.8(1.0)$ & $2.5(1.3)$ & $6.2(3.3)$ \\
\hline Mullidae & $8.8(4.6)$ & $6.7(3.0)$ & $4.2(2.1)$ & $3.6(1.4)$ & $4.6(1.1)$ & $4.5(2.9)$ & $3.6(1.1)$ \\
\hline Labridae & $7.3(3.3)$ & $5.1(3.4)$ & $8.2(6.3)$ & $9.8(6.5)$ & $2.5(0.9)$ & $7.0(3.1)$ & $6.3(1.5)$ \\
\hline Scaridae & $36.6(11.5)$ & $18.6(9.2)$ & $8.2(5.1)$ & $18.9(11.5)$ & $24.1(6.1)$ & $58.2(12.7)$ & $59.9(11.9)$ \\
\hline Acanthuridae & $22.4(7.7)$ & $17.4(8.8)$ & $14.7(9.4)$ & $16.9(9.5)$ & $16.3(4.5)$ & $20.3(8.7)$ & $29.3(10.1)$ \\
\hline Siganidae & $14.0(8.0)$ & $12.2(8.1)$ & $7.1(5.1)$ & $7.2(3.8)$ & $3.5(1.2)$ & $6.4(1.6)$ & $8.7(3.2)$ \\
\hline
\end{tabular}

latter), the scarid Scarus schlegeli, the acanthurid Ctenochaetus striatus and the siganid Siganus punctatus displayed similar trends, in density and biomass.

\subsection{Substrate characteristics, living organisms and correlations with fish descriptors}

Rocks represented the main substrate component for all of the seven sectors studied (figure 3). The second major component was sand on the east coast, and mud on the west coast. Differences found between sectors were not statistically significant due to the high variance of the data (one-way ANOVA, $\mathrm{P}>0.05$ for all substrate categories). This underlines that substrate characteristics may be considered as globally homogeneous, despite the fluctuations occurring between stations within each sector. Conversely, significant differences between sectors were found for the living organisms (one-way ANOVA,
$\mathrm{P}<0.05$ for each of the three categories) (figure 4). For macroalgae, no clear gradient could be detected, but the lowest values were found in sectors close to areas free of mining activities on both coasts. A decreasing gradient for both hard and soft corals appcarcd on the cast coast, although less pronounced for the latter. No gradient was found on the west coast, despite the fact that the highest value of live coral cover (hard coral) was observed on fringing reefs close to areas free of mining activities or ground erosion (figure 4).

Significant relationships between substrate and fish descriptors were not numerous (table $I V$ ). Some fish families were almost indifferent to substrate characteristics, such as Lutjanidae, Lethrinidae and Mullidae, whereas some others were more sensitive, such as Labridae and Scaridac. The living organisms did not significantly influence fish distribution, except the macroalgae but at a low level (table IV). Some substrate categories were rela- 


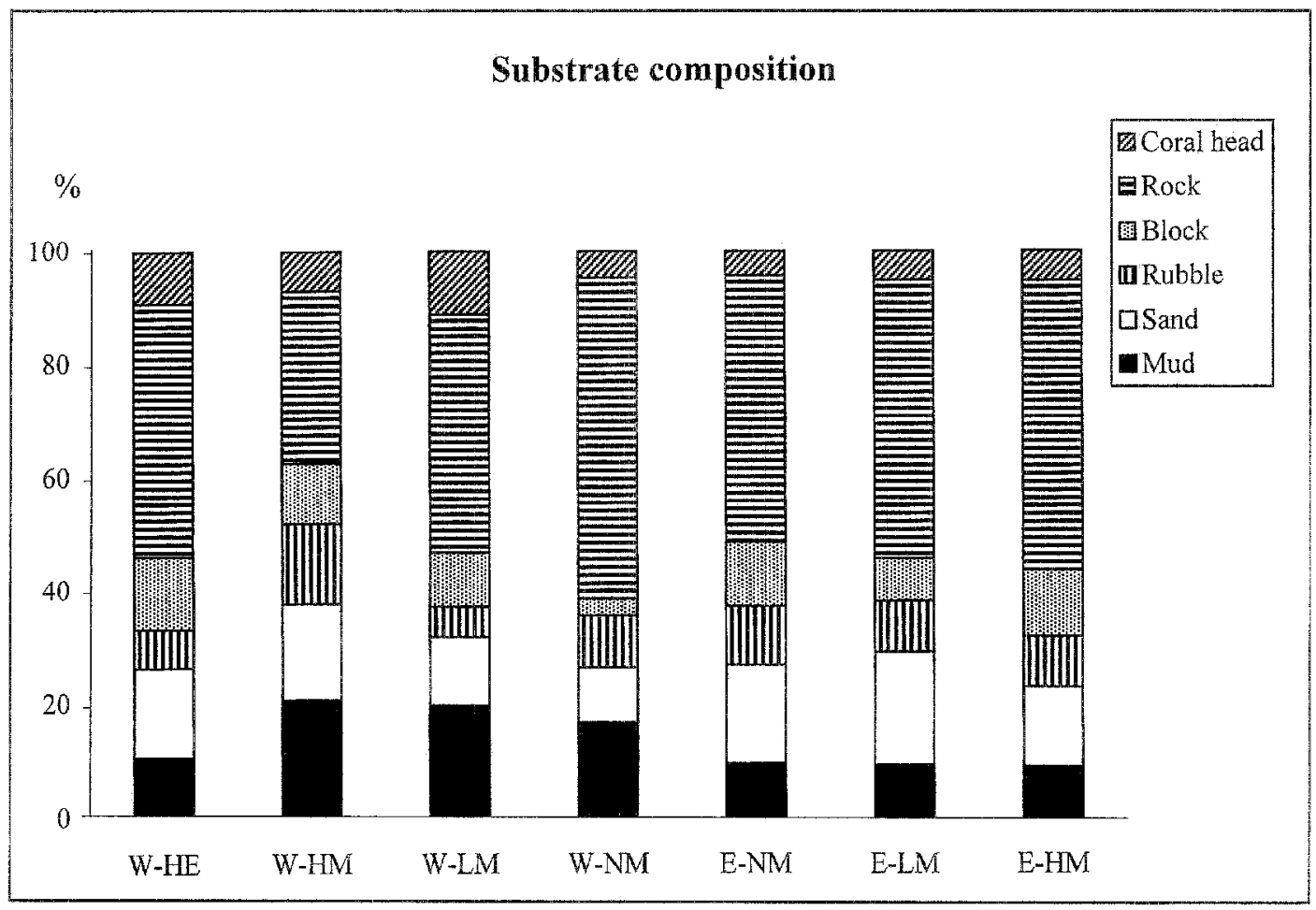

Figure 3. Mean composition of the substrate in the seven sectors studied. WHE = west coast, high erosion, WHM = west coast, high mining, $\mathrm{WLM}=$ west coast, low mining, $\mathrm{WNM}=$ west coast, non-mining, $\mathrm{ENM}=$ east coast, non-mining, $\mathrm{ELM}=$ east coast, low mining, and $\mathrm{EHM}=$ east coast, high mining.

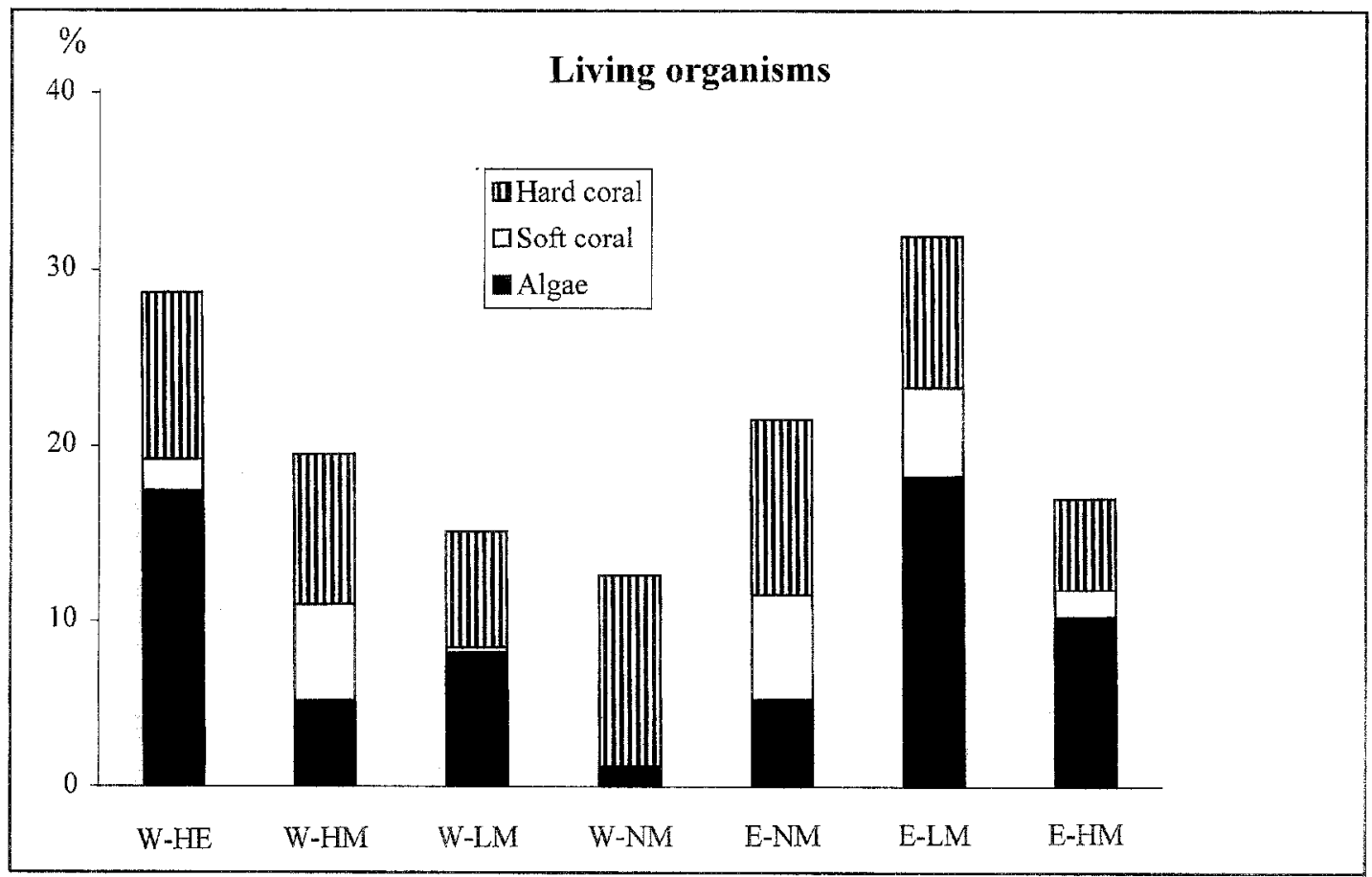

Figure 4. Mean cover of the substrate by living organisms in the seven sectors studied. WHE = west coast, high erosion, WHM = west coast, high mining, WLM = west coast, low mining, WNM = wcst coast, non-mining, ENM = east coast, non-mining, ELM - east coast, low mining, and $\mathrm{EHM}=$ east coast, high mining. 
Table IV. Summary of the significant relationships found between the fish descriptors and the substrate. Significance: $++=$ positive correlation at $\alpha=1 \%,+=$ positive correlation at $\alpha=5 \%,--=$ negative correlation at $\alpha=1 \%$, and - = negative correlation at $\alpha=5 \%$.

\begin{tabular}{|c|c|c|c|c|c|c|c|c|c|c|}
\hline Fish family & & Mud & Sand & Rubble & Block & Rock & $\begin{array}{l}\text { Coral } \\
\text { head }\end{array}$ & $\begin{array}{c}\text { Macro } \\
\text { algae }\end{array}$ & $\begin{array}{c}\text { Soft } \\
\text { coral }\end{array}$ & $\begin{array}{l}\text { Hard } \\
\text { coral }\end{array}$ \\
\hline \multirow[t]{2}{*}{ Serranidae } & Diversity & & - & & & & & & & \\
\hline & Density & & - & & & + & & ++ & & \\
\hline \multirow[t]{2}{*}{ Lutjanidae } & Density & + & & & & & & & & \\
\hline & Biomass & + & & & & & & & & \\
\hline Lethrinidae & Density & & + & & & & & & & \\
\hline Mullidae & Diversity & & & + & & & & & & \\
\hline \multirow[t]{3}{*}{ Labridae } & Diversity & - & & & + & & & & & \\
\hline & Density & & & - & + & & & + & & \\
\hline & Biomass & & & - & + & & & & & \\
\hline \multirow[t]{2}{*}{ Scaridae } & Diversity & - - & & & + & & & + & & \\
\hline & Density & - & & ++ & + & & & & & \\
\hline \multirow[t]{2}{*}{ Acanthuridae } & Diversity & & - & & & ++ & & & & \\
\hline & Density & - & & & & & & & & \\
\hline \multirow[t]{2}{*}{ Siganidae } & Diversity & - & & & & & & & & \\
\hline & Biomass & + & & - & & & & & & \\
\hline
\end{tabular}

tively important for determining fish distribution, such as mud and blocks, whereas some others did not have a significant importance, such as coral heads and rocks. These results indicate that commercial fish communities are globally not influenced by substrate characteristics at the level studied here.

\section{DISCUSSION}

Two main types of results appeared from this study. First, and this was unexpected, descriptors of fish communitics (species richness, density and biomass) displayed higher values on fringing reefs close to areas submitted to high mining activities or ground erosion levels. Second, the patterns found were more pronounced on the east coast than on the west coast. Different causes might be responsible for the patterns observed, acting alone or combined. They involved links with living organisms and substrate variables, differences in fishing pressure, differences in terrigeneous influence and rainfalls, and/or differences in geographical characteristics.
Although relationships between fish and substratum variables are not obvious in this study, it is well established that living organisms and substrate variables usually strongly influence distribution of fish communities. Correlations between topographic complexity and fish species richness is well documented [9, 33, 40, 47]. Conversely, correlation between topographic complexity and fish density is not so evident. Some authors found a positive correlation between these variables [47], whilst some others found only a low corrclation [33], or no significant correlation [38, 49]. Generally, small, territorial fish are the most sensitive to substrate variables, such as Chaetodontidae [2, 6, 41] or Pomacentridae $[9,48,54]$. However in the present work, we found only a low number of significant correlations between fish and local environment descriptors, underlining that commercial fish were globally not linked with living organisms or subtrate variables. Most of the commercial species are highly mobile and not linked to a particular spot on the reef [31]. Data for these large species are rare $[31,43,55]$. Large scale environmental descriptors, such as distance to the coast, water turbid- 
ity, percentage of carbonates in the sediment, are more adapted than precise substrate characteristics in understanding the distribution of these fish, as demonstrated by a study of fish communities in the northern lagoon of New Caledonia along a terrestrial runoff gradient [31]. However, in this study all stations studied are on coastal fringing reefs, and large scale environmental descriptors, such as distance to coast, percentage of carbonates in the sediment, or water turbidity are all similar between the different stations. In other words, the present work failed to find environmental descriptors, either locally or on a large scale, which could satisfactorily explain the differences in fish community structures observed between stations.

The second hypothesis which might explain the patterns observed involves differences in fishing pressure. Studies providing clear data on the effects of fishing activities on fish community structure are not numerous, particularly because fishing effects are generally treated as synonymous with overfishing [19]. Thus many studies of fishing effects have been based upon studies of localized catastrophic events rather than gradual changes linked to fishing activities under normal conditions [19, 44]. However, several studies have shown that the most detectable effects of fishing pressure are a decrease in mean size, density and/or biomass of species commonly targeted by the fisheries [18, 29, 36, 45]. Difference in fishing pressure exists between the sectors studied [26]. Although only small artisanal fisherics exist in all scctors, fishing pressure is globally higher on the west coast than on the east coast, with an average of $0.92 \mathrm{t} \mathrm{km}^{-2} \mathrm{vs}$ $0.30 \mathrm{t} \mathrm{km}^{-2}$ respectively $[25,30]$. Differences in fishing pressure between the sectors studied on the east coast are low (table V), from 0.20 to $0.40 \mathrm{t} \mathrm{km}^{-2}$, and cannot explain the magnitude of the patterns observed on this coast. Conversely, fluctuations of fishing pressure on the west coast are more pronounced, with values ranging from 0.15 to $2.80 \mathrm{t} \mathrm{km}^{-2}$. Two sectors showed high fishing pressure levels on the west coast, Kone and Népoui (figure 1): one is close to areas submitted to high mining activities, and the other is free of mining activities. Two other sectors showed low fishing pressure levels, Poum and Koumac: one is close to areas submitted to high natural ground erosion, and the other is free of mining activities. It remains thus difficult to establish a link between the intensily of fishing pressure and the patterns found, because similar fishing pressure levels occurred in sectors submitted to very different ground erosion.
Table V. Fishing pressure (in $t . \mathrm{km}^{-2}$ ) near the main villages close to the reefs studied (see figure I for location of the villages).

\begin{tabular}{llll}
\hline WEST COAST & \multicolumn{3}{c}{ EAST COAST } \\
\hline Poum & 0.16 & Touho & 0.18 \\
Koumac & 0.16 & Poindimié & 0.40 \\
K-Gomen & 0.22 & Houailou & 0.30 \\
Voh & 0.42 & Kouaoua & 0.15 \\
Koné & 2.78 & Canala & 0.34 \\
Népoui & 0.92 & & \\
\hline
\end{tabular}

Terrigeneous influence is the third set of factors which may explain our results. Studies investigating the possible role of terrigeneous influence on reef fish communities are not numerous $[43,51,52,55]$. Futhermore, although these studies mentioned the role of terrigeneous influence in structuring reef fish communities, none of them provides quantification of this phenomenon. Only one previous study in the northern lagoon of New Caledonia provided quantitative data, demonstrating clearly that a coast-to-ocean terrigeneous runoff gradient influences the distribution of fish assemblages [31]. The situation is different here, as fish assemblages are all located on coastal fringing reefs, but submitted to different ground erosion levels. Little is known on the trophodynamics of coral reefs, but productivity is expected to be greater in nutrient-rich waters than in nutrient-poor ones [35]. We suggest that high terrigeneous runoffs bring important quantities of particular matter and nutrients into coastal waters. This might favour pelagic primary production, zooplankton and consequently fish production, as suggested for the southwestern lagoon of New Caledonia [16], but the existence of a link between primary production and ground erosion level is not demonstrated in the area studied. Nevertheless, it was shown that large schools of small pelagic fish, such as anchovies and sardines, mostly occurred in bays characterized by highly turbid waters and particularly near Népoui and Canala villages, which are close to areas submitted to high mining activity (see figure I) [10]. This hypothesis implies that ground erosion could have some positive effects on coastal fish communities. However, it must be considered with caution as an explanation of our results for at least two reasons. Firstly, most of the soils found in mining areas are relatively poor in nutrients as they originate from peridotite. Secondly, they contain high levels of heavy metais which might have detrimental effects, in terms of bio contamination, bio-concentration, physiology or toxicity [12]. Lastly, the sediments brought by 
these soils are very fine and easily stirred by trade winds, generating highly turbid waters which may slow down primary production or the growth of corals.

A fourth hypothesis, based on difference in raintall and/ or geographical characteristics, may be proposed to explain the fact that the observed patterns are more apparent on the east coast than on the west coast. As already observed in the southwestern lagoon of New Caledonia [16], we assume that surfaces of drainage systems do not have a significant importance in structuring costal fish communities at the spatial scale studied here. Total land surfaces close to the seven sectors are largely higher than the surface of each drainage system existing in each sector. Thus, the possible effects of ground erosion and mining activities might be very localized, and detectable mainly at a smaller spatial scale. Avẹrage annual rainfalls are more than twice on the east coast (about $2.3 \mathrm{~m} \mathrm{yr}^{-1}$ ) than on the west coast $\left(1.0 \mathrm{~m} \mathrm{yr}^{-1}\right)$, mainly due to the mountain relief [37]. Rainfall is also more evenly distributed throughout the year on the east coast. In addition, the east coast is also characterized by a rugged topography and abrupt coastlines, whereas the west coast is mainly characterized by plains and hills. Terrigeneous runoff is thus more important and stable over time on the east coast than on the west coast, despite seasonal variations. If we assume that the previous hypothesis on terrigeneous influence is valid, at least partly, then the combination of these two factors could generate a clearly defined response of the fish communities on the east coast, in particular because the reef ecosystems under these conditions may be more productive $[16,35]$. Conversely, terrigeneous runoffs occur more as spikes on the west coast, and might gencrate a more chaotic response of fish communities than on the east coast.

\section{CONCLUSIONS}

The factors which may explain spatial patterns often act in synergy and their respective roles are sometimes difficult to determine [54]. Although abiotic factors, i.e. differences in terrigeneous influence, average rainfalls and geographical characteristics, are likely to play inportant roles in the patterns found, their relative contribution cannot yet be clearly assessed and quantified. Howevcr, this work constitutes a first step in understanding the factors which structure fish assemblages on New Caledonian fringing reefs. Future research on coastal fish communities should seek to identify the ecological processes underlying these patterns and to determine both their respective roles and their relative importance at the spatial scale recognized in this study. In particular it will be interesting to investigate non-commercial fish [13], such as territorial and/or shortliving species because they are probably more sensitive to a possible effect of mining activities than mobile and freeranging ones (such as those studied here), closely combined with a quantification of the possible impacts of heavy metals on coastal communities.

\section{Acknowledgements}

This work was funded by the Northern Province of New Caledonia (development grant \# 3160 between the French Government and Northern Province of New Caledonia). The authors are grateful to N. Audran, P. Boblin, G. MouTham, J.R. Paddon and P. Malestroit for their invaluable help in the field, and to S. Dupont (SMAI, Service des Méthodes Administratives et Informatiques) for his help in SPOT image interpretation. They thank the anonymous reviewers for their constructive comments on the manuscript.

\section{REFERENCES}

[1] Ahmed-Michaux P., Roos W., Images de la population de la Nouvelle-Calédonie, principaux résultats du recensement de 1996, Rap. ITSEE, 1997, 64 p.

[2] Bell J.D., Galzin R., Influence of live coral cover on coral reef fish communities, Mar. Ecol. Prog. Ser. 15 (1984) 262-274.

[3] Bell J.D., Galzin R., Distribution of coral and fish in the lagoon of Mataiva: potential for increase through mining? Proc. 6th Intern. Coral Reef Symp. Townsville 2 (1988) 347-352.
[4] Bell J.D., Craik G.J.S., Pollard D.A., Russell B.C., Estimating length frequency distributions of large reef fish underwater, Coral Reefs 4 (1985) 41-44.

[5] Bouchon C., Bouchon-Navaro Y., Louis M., Laborcl J. Influence of the degradation of coral assemblages on the fish communities of Martinique (French West Indies), Proc. 38th Gulf Carib. Fish. Inst. 1 (1987) 452-468.

[6] Bouchon-Navaro Y., Bouchon C., Correlations between chaetodontid fishes and coral reef communities of the Gulf of Aqaba (Red Sea), Env. Biol. Fish. 25 (1989) 47-60. 
[7] Buckland S.T, Anderson D.R., Burnham K.P., Laake J.L., Distance sampling. Estimating abundance of biological populations, Chapman \& Hall, London, 1993, 446 p.

[8] Burnham K.P., Anderson D.R., Laake J.L., Estimation of density from line transect sampling of biological populations, Wildlife Monogr. 72 (1980) 1-202.

[9] Chabanet P., Ralambondrainy H., Amanieu M., Faure G,, Galzin R., Relationships between coral reef substrata and fish, Coral Reefs 16 (1997) 93-102.

[10] Conand F., Biologie et écologie des poissons pélagiques du lagon de Nouvelle-Calédonie utilisables comme appâts thoniers, thèse doct. univ. Bretagne occidentale, 1988, $233 \mathrm{p}$.

[11] Dawson-Shepherd A.R., Warwick R.M., Clarke K.R., Brown B.E., An analysis of fish community responses to coral mining in the Maldives, Env. Biol. Fish. 33 (1992) 367-380.

[12] Duhet D., Les métaux dans l'environnement marin de la Nouvelle-Calédonie, recherche bibliographique, essai de synthèse, perspectives de recherches, Rap. Orstom Nouméa (1992) $128 \mathrm{p}$.

[13] Fichez R., Newell P., South R., The Ecotrope programme: looking at terrigeneous and anthropogenic influences on coral reef lagoons of the Pacific, Proc. Mar. Benthic Habit. Conf. Nouméa 1 (1997) 47.

[14] Galzin R., Effects of coral dredging on fish fauna in the lagoon of Grand-cul-de-sac-marin, Guadeloupe, French West Indies, Proc. 4th Intern. Coral Reef Symp. Manilla 1 (1981) 115-121.

[15] Grigg R.W., Dollar S.J., Natural and anthropogenic disturbance on coral reefs, in: Dubinsky Z. (Ed.), Ecosystems of the world, Coral reefs, Elsevier, New York, 1990, pp. 439-452.

[16] Grimaud J., Structure des peuplements de poissons des récifs frangeants du lagon sud-ouest de Nouvelle-Calédonie, Rap. mém. DEA, univ. Paris-6 (1997) $30 \mathrm{p}$.

[17] Harmelin-Vivien M.L., The effects of storms and cyclones on coral reefs: a review, J. Coast. Res. 12 (1995) 211-231.

[18] Jennings S., Grandcourt E.M., Polunin N.V.C., Effects of fishing on the diversity, biomass and trophic structure of Seychelles' reef fish communities, Coral Reefs 14 (1995) 225-235.

[19] Jennings S., Lock J.M., Population and ecosystem effects of reef fishing, in: Polunin N.V.C., Roberts C.M. (Eds.), Reef fisheries, Chapman \& Hall, London, 1996, pp. 193-218.

[20] Johannes R.E., Pollution and degradation of coral reefs, in: Wood E.J., Johannes R.E. (Eds.), Tropical marine pollution, Elsevier, New York, 1975, pp. 13-50.

[21] Kulbicki M., Correlation between catch data from bottom longlines and fish censuses in the SW lagoon of New Caledonia, Proc. 6th Intern. Coral Reef Symp., Townsville 2 (1988) 305-312.

[22] Kulbicki M., How acquired behaviour of commercial reef fish may influence results obtained from visual censuses, J. Exp. Mar. Biol. Ecol. 222 (1998) 11-30.

[23] Kulbicki M., Wantiez L., Comparison between fish bycatch from shrimp trawlnet and visual censuses in St Vincent Bay, New Caledonia, US Fish. Bull. 88 (1990) 667-675.
[24] Labrosse P., Letoumeur Y., Audran N., Boblin P., Kulbicki M. Évaluation des ressources en poissons démersaux commerciaux des lagons de la Province Nord de la Nouvelle-Calédonie, Résultats des campagnes d'échantillonnage de la zone nord, Rap. Conv. Sci. Mer Biol. Mar. Orstom Nouméa 16 (1996) $118 \mathrm{p}$.

[25] Labrosse P., Letourneur Y., Audran N., Boblin P., Malestroit P., Paddon J.R., Kulbicki M., Évaluation des ressources en poissons démersaux commerciaux des la-gons de la Province Nord de la Nouvelle-Calédonie, Résultats des campagnes d'échantillonnage de la zone ouest, Rap. Conv. Sci. Mer Biol. Mar: Orstom Nouméa 17 (1997) 110 p.

[26] Labrosse P., Letourneur Y., Paddon J.R., Kulbicki M., Incidences de la pression de pêche sur les stocks de poissons démersaux commerciaux du lagon ouest de la Province Nord, Rap. Conv. Sci. Mer Biol. Mar. Orstom Nouméa 19 (1997) 15 p.

[27] Legendre L., Legendre P., Écologie numérique, II : La structure des données écologiques, $2^{\mathrm{e}}$ édition. Masson, Paris, 1984, $335 \mathrm{p}$.

[28] Letourneur Y., Dynamics of fish communities on Reunion frimging reefs, Indian Ocean, I. Patterns of spatial distribution, J. Exp. Mar. Biol. Ecol. 195 (1996) 1--30.

[29] Letourneur Y., Réponses des peuplements et populations de poissons aux réserves marines, Le cas de l'île de Mayotte, océan Indien occidental, Ecoscience 3 (1996) 442-450.

[30] Letourneur Y., Labrosse P., Audran N., Boblin P., Paddon J.R., Kulbicki M., Évaluation des ressources en poissons démersaux commerciaux des lagons de la Province Nord de la NouvelleCalédonie, Résultats des campagnes d'échantillonnage de la zone est, Rap. Conv. Sci. Mer Biol. Mar. Orstom Nouméa 20 (1997) $130 \mathrm{p}$.

[31] Letourneur Y., Kulbicki M., Labrosse P., Spatial structure of commercial reef fish communities along a terrestrial runoff gradient in the northern lagoon of New Caledonia, Env. Biol. Fish. 51 (1998) 141-159.

[32] Letourneur Y., Kulbicki M., Labrosse P., Length-weight relationships of fishes from coral reefs and lagoons of New Caledonia, An update, Naga The Iclarm Quart. 21 (1998) 3946.

[33] Luckhurst B.E., Luckhurst K., Analysis of the influence of substrate variables on coral reef fish communities, Mar. Biol. 49 (1978) 317-323.

[34] Naïm O., Seasonal responses to eutrophication of a fringing reef (Reunion Island, Western Indian Ocean), Mar. Ecol. Prog. Ser. 99 (1993) 137-151.

[35] Polunin N.V.C., Trophodynamics of reef fisheries productivity, in: Polunin N.V.C., Roberts C.M. (Eds.), Reef fisheries, Chapman \& Hall, London, 1996, pp. 113-136.

[36] Polunin N.V.C., Robcrts C.M., Greater biomass and value of target coral reef fishes in two small Caribbean marine reserves, Mar. Ecol. Prog. Ser. 100 (1993) 167-176.

[37] Richer-de-Forges B., Bargibant G., Menou J.L., Garrigue C., Le lagon sud-ouest de la Nouvelle-Calédonie, Observations préalables à la cartographie des fonds meubles, Rap. Sci. Tech. Sci. Mer Orstom Nouméa 45 (1987) 110 p. 
[38] Risk M.J., Fish diversity on a coral reef in the Virgin Islands, Atoll Res. Bull. 193 (1972) 1-6.

[39] Roberts C.M., Effects of fishing on the ecosystem structure of coral reefs, Conserv. Biol. 9 (1995) 988-995.

[40] Roberts C.M., Ormond R.F., Habitat complexity and coral reef fish diversity and abundance on Red Sea fringing reefs, Mar. Ecol. Prog. Ser. 41 (1987) 1-8.

[41] Roberts C.M., Dawson-Shepherd A.R., Ormond R.F., Large scale variation in assemblage structure of Red Sea butterfly fishes and angelfishes, J. Biogeogr. 19 (1992) 239-250.

[42] Romesburg H.C., Exploring, confirming and randomization tests, Comput. Geosci. 11 (1985) 19-37.

[43] Russ G.R., Distribution and abundance of herbivorous grazing fishes in the central Great Barrier Reef, I. Levels of variability across the entire continental shelf, Mar. Ecol. Prog. Ser. 20 (1984) 23-34.

[44] Russ G.R., Coral reef fisheries: effects and yields, in: Sale P.F. (Ed.) The Ecology of Fishes on Coral Reefs, Academic Press, San Diego, 1991, pp. 601-635.

[45] Russ G.R., Alcala A.C., Effects of intense fishing pressure on an assemblage of coral reef fishes, Mar. Ecol. Prog. Ser. 56 (1989) 13-27.

[46] Salvat B. (Ed.) Human impacts on coral reefs: facts and recommendations, Antenne Museum EPHE, French Polynesia, $1987,253 \mathrm{p}$.

[47] Sano M., Shimizu M., Nose Y., Changes in structure of coral reef fish communities by destruction of hermatypic corals: observational and experimental views, Pacif. Sci. 38 (1984) 51-79.

[48] Sano M., Shimizu M., Nose Y., Long-term effects of destruction of hermatypic corals by Acanthaster planci infestation on reef fish communities at Iriomote Island, Japan. Mar. Ecol. Prog. Ser. 37 (1987) 191-199.

[49] Talbot F.H., Russell B.C., Anderson G.R.V., Coral reef fish communities: unstable, high diversity systems? Ecol. Monogr. 48 (1978) 425-440.

[50] Thresher R.E., Gunn J.S., Comparative analysis of visual census techniques for highly mobile, reef-associated piscivores (Carangidae), Env. Biol. Fish. 17 (1986) 93-116.

[51] Wantiez L., Thollot P., Kulbicki M., Effects of marine reserves on coral reef fish communities from five islands in New Caledonia, Coral Reefs 16 (1997) 215-224.

[52] Williams D. McB., Patterns in the distribution of fish communities across the central Great Barrier Reef, Coral Reefs 1 (1982) $35-43$.

[53] Williams D. McB., Temporal variation in the structure of reef slope fish communities (central Great Barrier Reef): shortterm effects of Acanthaster planci infestation, Mar. Ecol. Prog. Ser. 28 (1986) 157-164.

[54] Williams D. McB., Patterns and processes in the distribution of coral reef fishes, in: Sale P.F. (Ed.), The Ecology of Fishes on Coral Reefs, Academic Press, San Diego, 1991, pp. 437-474.

[55] Williams D. McB., Hatcher A.I., Structure of fish communities on outer slopes of inshore, mid-shelf and outer shelf reefs of the Great Barrier Reef. Mar. Ecol. Prog. Ser. 10 (1983) $239-250$. 